\title{
Lecturas y Traducción: Dormir al sol de Adolfo Bioy Casares
}

\author{
Las cosas se desataban de sus nombres \\ Al borde de mi cuerpo \\ Yo fluía \\ Entre los elementos desceñidos \\ Octavio Paz \\ (de "Soltura," Ladera Este)
}

\begin{abstract}
El ejercicio de traducción supone un reconocimiento de lo "esencial", de aquello que permanece idéntico a pesar del cambio de idioma, de aquello que permite el flujo de un medio a otro. Traducir es, así, un modo privilegiado de lectura que se enmascara bajo el pretexto de que hay una presencia de lo escrito que supera el idioma y precipita modos de transcripción en otros. La traducción es, por eso, siempre plural; el texto ofrecido es una versión de otro que se toma como original, su presencia se constituye por la tensión para alcanzar una relación de mismidad con algo que por definición deberá permanecer fuera. Dormir al sol, 1 la última novela de Bioy Casares, se estructura con la sospecha de la posibilidad de una metamorfosis que preserva cierta parte reconocible como esencial. La novela se divide en dos partes, una que ocupa casi todo el libro redactada por Lucio Bordenave y otra por Félix Ramos. Félix Ramos es un personaje que guarda una relación especular con el lector de la obra; Lucio Bordenave escribe para él y procura persuadirlo de las características de su aventura. Su papel de redactor de la última parte de la novela consiste en otorgar existencia al relato de Bordenave al referirse a la recepción del texto. Su testimonio es el de un lector que puede opinar sobre Bordenave mejor que el lector que está "afuera" porque le conoce y participa dentro del círculo de ficción que hace posible a Bordenave. Tiene el privilegio de haber sido tomado como punto de partida de la cadena que inicia Bordenave al contar su aventura. Y también cierra la cadena ya que el juego entre él y Bordenave es un modelo reducido de lo que ocurre en la lectura de cualquier novela. Autor y lector han sido transfigurados en Bordenave y Félix Ramos; Bordenave es un lector desconfiable que escribe desde un presunto manicomio y Ramos un crítico de su texto que padece de la inevitable complicidad que implica su conocimiento. La trama de la novela construye, así, la ilusión de ser perfectamente cerrada por depender de los dos polos que hacen posible la escritura y la lectura.
\end{abstract}

Bordenave está obsesionado por saber qué ama de su mujer, si el cuerpo o el alma; su visión de Diana es fragmentaria y detallada:

Yo me muero por su forma y su tamaño, por su piel rosada, por su pelo rubio, por sus manos finas, por su olor, y sobre todo, por sus ojos incomparables. (p. 17)

${ }^{1}$ Las citas corresponden a Dormir al sol (Buenos Aires: Emecé, 1974). 
Si Diana no es ella misma en unidad indisoluble, se abre la posibilidad de que sus partes sean integradas a un sistema de organización distinto. La novela expande precisamente esta imagen. Un Sanatorio Frenopático donde se practican operaciones que intercambian partes físicas y almas con el uso de perros es el espacio donde las intervenciones sirven para caricaturizar la imagen inicial por medio de la amplificación de sus consecuencias. Los cuerpos y las almas son separables luego de misterioso análisis. El problema es saber si el resultado de la operación devuelve el mismo objeto que entró al sanatorio, si existe una continuidad entre ellos y sus nombres que permita el reconocimiento de lo mismo, lo permanente a través de los cambios. Diana tiene dos dobles: su hermana Adriana María y una perra que posee el alma que le sacaron en el Frenopático. Ambas se le parecen y se confunden con ella al mismo tiempo que parecen diferenciarse. Su hermana tiene otro color de pelo pero el relato de Bordenave acentúa que si no fuera por este detalle él las confundiría; la perra tiene su alma y hay momentos en la narración en los cuales Bordenave sugiere que es esto lo que ama.

Diana tiene el alma "sana" de otra. Es una versión mejorada de sí misma; una paciente curada que sale de un sanatorio. Los términos en que Bordenave describe el tratamiento son alternativamente de cura o cambio total. Diana es ella en la medida en que es su nombre y su cuerpo. La perra es ella en la medida en que su alma y Adriana María también es ella en la medida en que ambas son casi iguales de cuerpo. Bordenave está loco según los criterios del Frenopático. La información sobre las duplicaciones y fragmentaciones de Diana nos llega por una narración escrita desde el sanatorio dirigida a Félix Ramos, un antiguo enemigo: El giro paranoico que Bordenave hace al final;

Tuve una corazonada por demás ingrata: la señora que hablaba con Samaniego era mi señora. El doctor le decía que para favorecerme no iba a perjudicarla. Como en una pesadilla Diana estaba en contra de mi. (p. 213)

lo convierte en un narrador desconfiable, en el hacedor de un discurso que define a los otros en términos de conspiración. El haber elegido a un enemigo para recibir su testimonio es parte del cuadro que caracteriza a su texto como una versión de algo que queda velado. Bordenave es relojero. La reparación de relojes guarda estrecha relación con el tiempo estático de una novela que, al desautorizar la voz del narrador "principal" "queda detenida en la formulación de la fisura por la cual el discurso fracasa y sólo le resta nombrar como referentes a los puntos que le sirven de polos. Félix Ramos es el polo receptor del informe de Bordenave y su corto relato insinúa la posibilidad de que éste haya estado internado en el Frenopático y dado de alto sutilmente convertido en otro. Pero también su testimonio es desconfiable. Incurre en contradicciones al explicar su relación anterior con Bordenave:

Ante todo me parece raro que Bordenave se dirija a mí; al fin y al cabo estamos distanciados. También me parece raro que Bordenave me trate de usted; al fin y al cabo nos conocemos desde la infancia. (p. 226)

Félix Ramos está implicado en la historia de Bordenave con una intensidad que impide su actuación de crítico "objetivo". Su testimonio está viciado, su participación en el círculo de Bordenave lo convierte en testigo-actor. Bordenave y Ramos participan de un continuo que 
impide su diferenciación; la última frase de Ramos:

Todo el asunto me pareció, amén de confuso, amenazador. Resolví, pues, olvidarlo por un tiempo. (p. 229).

señala el espacio en que se unen y abre la posibilidad de que una averiguación más detallada por parte de Ramos, similar a la que Bordenave hiciera con respecto a la internación de Diana, lo ponga en manos del Frenopático. Bordenave le ha escrito su historia a un enemigo que guarda una relación especular con él y que, al leerla, la transcribe traduciendo el destino de Bordenave en el propio. Las figuras dibujadas por los trasplantes de cuerpos y almas existen en el juego menos explícito entre Ramos y Bordenave. El discurso de la novela es la maquinaria de cambios del Frenopático.

Dormir al sol privilegia en su título unas palabras del médico del Frenopático:

Imagino un perro, durmiendo al sol, en una balsa que navega lentamente aguas abajo, por un río ancho y tranquilo.

- ¿Y entonces?

- Entonces-contestó-imagino que soy ese perro y me duermo. (p. 211)

Como en "Axolotl" ${ }_{2}$ imaginar es volverse lo imaginado. Dormir es sustitución de un sujeto por otro, un acto de reconocimiento que es, simultáneamente, autodestrucción.

La hipótesis de pasajes de cuerpos y almas tiende a negar la existencia de una esencia que permanezca a pesar de los cambios. En los juegos especulares de la novela Bordenave y Ramos se confunden, las Dianas se multiplican y el desarrollo de un argumento es sustituido por una trama que relativiza la información del texto.

Como en otras novelas de Bioy Casares, especialmente Plan de evasión y La invención de Morel, la novela tiende a presentarse como una metáfora de su maquinaria de producción.

The Jobns Hopkins University

ALICIA BORINSKY

\footnotetext{
${ }^{2}$ Estudiamos la problemática del conocimiento fusión de sujeto y objeto en un ejercicio autodestructivo tal cual aparece en Axolotl de Julio Cortázar en un trabajo de próxima publicación.
} 
